\title{
Invitro and Field Evaluation of Compost tea and Seaweed Formulation on Leaf Blight of Sunflower
}

\author{
Shadab M. Khatib*, K. Karuna and Dattatreya \\ Department of Plant Pathology, College of Agriculture, UAS, GKVK, \\ Bengaluru-560065, India \\ *Corresponding author
}

A B S T R A C T

Keywords

Alternaria

helianthi,

Sunflower,

Compost tea,

Seaweed, in vitro

Article Info

Accepted:

12 December 2020

Available Online:

10 January 2021
Sunflower crop suffers from many diseases of which Alternaria blight has been considered as a potentially destructive disease. The objective of this study was in vitro evaluation and to study field efficacy of compost tea and seaweed formulation on leaf blight of sunflower. In vitro evaluation of compost tea revealed that maximum inhibition of $A$. helianthi was recorded in compost tea at 25 per cent $(60.5 \%)$ followed by compost tea at 20 per cent $(58.5 \%)$ and 15 per cent $(53.8 \%)$. In field conditions, foliar spray of compost tea at the rate of 1:10 ratio at $30,45 \mathrm{DAS}$ and propiconazole at $1 \mathrm{mlL}^{-1}$ at $60 \mathrm{DAS}$ increased the growth parameters like plant height $(245.93 \mathrm{~cm})$, stem girth $(4.60 \mathrm{~cm})$, number of leaves (9.35) and chlorophyll content (42.97). Foliar spray of compost tea with propiconazole was effective in controlling the Alternaria blight of sunflower with least disease severity $(10.37 \%)$ and higher yield $\left(2201.41 \mathrm{Kg} \mathrm{ha}^{-1}\right)$ which was on par with foliar spray of seaweed formulation (LBD-1) at 30, 45 DAS and propiconazole at 60 DAS with disease severity 12.32 per cent and seed yield of 1928.04 Kg ha ${ }^{-1}$.

\section{Introduction}

Sunflower (Helianthus annuus L.) a member of family Asteraceae (Compositae) is an important edible oilseed crop. In the world, sunflower ranks fourth in area after soybean, rapeseed and groundnut. North America is the native of sunflower and since ancient times it was grown as an ornamental plant. In 1969, it was introduced into India for the first time as oilseed crop. Presently in India, the sunflower crop occupies an area about 3.81 lakh ha with a production of 2.51 lakh tonnes and productivity of $660 \mathrm{Kg} \mathrm{ha}^{-1}$. Sunflower is being grown in India across Karnataka, Maharastra and Andhra Pradesh. Among these, Karnataka occupies first position accounting to 2.20 lakh ha with a production of 0.98 lakh tonnes and productivity of $445 \mathrm{~kg}$ $\mathrm{ha}^{-1}$ (Anon., 2017). Among the major diseases 
of sunflower, Alternaria blight caused by Alternaria helianthi (Hansf.) Tubaki and Nishihara has been considered as a potentially destructive disease in many parts of countries growing sunflower (Allen et al., 1983) and in north Karnataka (Shankergoud et al., 2006).

Balasubramanyam and Kolte (1980a) reported that the Alternaria blight significantly reduced average flower size, number of seeds per head, seed weight, seed yield per plant and also oil content. Depending on the extent of infection, the loss in the yield varied from 11.30 to 73.33 per cent (Reddy and Gupta, 1977). Several effective pesticides for the control of Alternaria leaf blight have been recommended but they are not regarded to be long term solutions, due to fungicide residue, exposure to heal the risk, concerns of expense and other environmental hazards. In this experiment, we have used biological controls like compost tea and seaweed formulation. Compost tea is a liquid extract made from compost that contains a variety of nutrients, growth compounds and beneficial microorganisms. The microorganisms in compost tea may potentially produce biomolecules with antibiosis potential, contributing to disease suppression of either Phytophthora infestans or Magnoporthe griseae (Anil et al., 2017).

Seaweed extract is one of the biostimulants which can be applied as a foliar spray and enhance plant growth, tolerance to abiotic stress, photosynthetic activity and resistance to diseases, improving the yield and productivity of many crops (Sharma et al., 2014). Therefore in view of the importance of the crop and disease management, present investigation on Alternaria blight of sunflower was conducted to assess the in vitro evaluation of compost tea against Alternaria helianthi and to study the field efficacy of compost tea and seaweed formulation on leaf blight of sunflower.

\section{Materials and Methods}

The present investigation was undertaken during 2018-19 at Zonal Agricultural Research Station, University of Agricultural Sciences, GKVK, Bengaluru. The experimental site is located in the eastern tract (Zone 5) of Karnataka at $12^{\circ} 58^{\prime} \mathrm{N}$ latitude and $77^{\circ} 35^{\prime} \mathrm{E}$ longitude and at an altitude of $930 \mathrm{~m}$ above mean sea level.

\section{In vitro evaluation of compost tea against Alternaria helianthi}

The efficacy of compost tea was evaluated against $A$. helianthi on Potato dextrose agar medium at different concentrations using poisoned food technique (Vincent, 1947). Sterilized potato dextrose agar was prepared and autoclaved. The agar medium was cooled to $50{ }^{\circ} \mathrm{C}$. Compost tea was dissolved in sterilized water to make the stock solution. Appropriate quantity of stock solution was added to PDA, to get the desired concentration of the compost tea, the flasks were agitated gently to aid uniform dispersion of the compost tea solution into the medium. About 15 to $20 \mathrm{ml}$ of poisoned PDA was poured into $90 \mathrm{~mm}$ Petri plates and allowed to solidify. Three replications were maintained for each treatment. $5 \mathrm{~mm}$ disc of the actively growing test fungal culture of $A$. helianthi were obtained with a sterilized cork borer and transferred aseptically to the centre of the poisoned medium in each of the Petri plates. Control was maintained with the pathogen under similar conditions on PDA without poisoning. Inoculated plates were incubated for 21 days at $27 \pm 1^{\circ} \mathrm{C}$ and the colony diameter was recorded by measuring the radial growth of the fungus in two directions at a right angle to each other and the average diameter was calculated. The percent inhibition of the growth over control was calculated by following the equation (Vincent, 1947). 
$\mathrm{I}=\frac{\mathrm{C}-\mathrm{T}}{\mathrm{C}} \times 100$

Where,

$\mathrm{I}=$ Per cent inhibition of mycelial growth

$\mathrm{C}=$ Radial growth of pathogen in control (mm)

$\mathrm{T}=$ Radial growth of pathogen in treatment (mm)

To study the field efficacy of compost tea and seaweed formulation on leaf blight of sunflower

Field experiment was conducted at Zonal Agricultural Research Station, GKVK, Bengaluru during Kharif 2018-19 for the management of leaf blight of sunflower.

$\begin{array}{ll}\text { Plot size } & : 4.2 \mathrm{~m} \times 4.5 \mathrm{~m} \\ \text { Hybrid } & : \text { KBSH-44 } \\ \text { Space } & :(60 \times 30) \mathrm{cm} \\ \text { Date of sowing } & : 19-08-2018 \\ \text { Design } & : \text { RCBD } \\ \text { Treatment } & : 7 \\ \text { Replication } & : 3\end{array}$

Standard agronomic practices were followed to grow the crop.

\section{Treatment details are as follows}

T1: Foliar spray of compost tea (1:10) @ 30, 45 and 60 DAS

T2: Foliar spray of seaweed formulation (LBD-1)@ $2 \mathrm{mlL}^{-1}$ at 30, 45 and 60 DAS

T3: Foliar spray of compost tea (1:10) @30, 45 DAS and propiconazole @ $1 \mathrm{mlL}^{-1}$ at 60 DAS

T4: Foliar spray of seaweed formulation (LBD-1) @ $2 \mathrm{mlL}^{-1}$ at 30, 45 DAS and propiconazole@1 $\mathrm{mlL}^{-1}$ at 60 DAS

T5: Foliar spray of propiconazole @ $1 \mathrm{mlL}^{-1}$ at 45 and 60 DAS

T6: Foliar spray of mancozeb @ $3.0 \mathrm{gL}^{-1}$ at 45 and 60 DAS
T7: Control

\section{Observations recorded}

Five plants were selected randomly for recording observations and the mean of five plant observations were used for further analysis.

\section{Plant height (cm)}

The plant height was measured using a metric scale from the base of the plant to the point of attachment of the capitulum at 90 days after sowing and expressed in centimeters.

\section{Number of leaves (units)}

The number of fully opened leaves from the base to the tip of the terminal bud was counted at 90 days after sowing.

\section{Stem girth $(\mathrm{cm})$}

The stem girth was measured at the middle point of stalk at 90 days after sowing by using vernier calipers which is expressed in centimeters.

\section{Chlorophyll content (nmol/mg)}

The chlorophyll content was measured using SPAD meter at 90 days after sowing and then values were expressed in $\mathrm{nmol} / \mathrm{mg}$.

\section{Seed yield $\left(\mathrm{Kg} \mathrm{ha}^{-1}\right)$}

At harvest stage, the weight of well dried and cleaned seeds from each treatment was recorded in kilograms, extrapolated and expressed in kilograms per hectare.

\section{Disease severity (\%)}

Assessment of the severity of Alternaria leaf blight was simultaneous with the evaluation of leaf area, with the aid of diagrammatic 
scale. Marked plants affected by the other diseases were discarded. Per cent disease severity was recorded at 50 per cent of flowering. Disease severity was calculated using the formula.

Disease severity $(\%)=\frac{\text { Area of plant tissue affected by disease }}{\text { Total area }} \times 100$

\section{Statistical analysis}

The field experimental data was analysed statistically by Fischer's method of analysis of variance by Panse and Sukhatme (1967). The level of significance used in the $F$ test was $\mathrm{P}=0.05$. The critical difference was worked out wherever F-test was significant.

\section{Results and Discussion}

Experiments were conducted on various aspects of Alternaria blight of sunflower with reference to in vitro and field evaluation studies of biological controls at GKVK, Bengaluru, during 2018-19. The results obtained are presented and discussed below.

\section{In vitro evaluation of compost tea against Alternaria helianthi}

The effect of compost tea at different concentrations on growth of $A$. helianthi was studied by using poisoned food technique (Table 1).

The radial growth of the pathogen was significantly superior over control in all the concentrations of the compost tea tested. The radial growth of the pathogen was maximum $(35.00 \mathrm{~mm})$ in compost tea tested at 2.5 per cent which is on par with compost tea at 5,10 and 15 per cent.

The radial growth of the pathogen was 29.00 $\mathrm{mm}$ in compost tea at 20 per cent which was on par with compost tea at 25 per cent, whereas the radial growth of pathogen in control (without compost tea) was $70 \mathrm{~mm}$ (Plate 1, Fig. 1).

Maximum per cent inhibition $(60.50 \%)$ of pathogen was recorded in compost tea at 25 per cent followed by compost tea at 20 per cent $(58.50 \%)$ and 15 per cent $(53.80 \%)$. Least inhibition of pathogen over control was observed on compost tea at rate of 2.5 per cent.

The above findings are in close agreement with the findings of Luo et al., (2019) who reported that mycelial growth was reduced in B. cinerea and A. alternata by up to 49 and 53 per cent, respectively due to different bacterial antagonists present in disease suppressive composts for controlling fruit rot of bell pepper.

Haggag and Saber (2007) also conducted an in vitro evaluation of compost tea against Alternaria porri in onion and Alternaria solani in tomato and results revealed that there was inhibition of fungal growth up to 80.2 and 83.8 per cent, respectively.

Pane et al., (2012) also showed compost tea was most effective in suppressing the growth of three pathogens of tomato viz., Alternaria alternate (72.5\%), Botrytis cinerea $(37.5 \%)$ and Pyrenochaeta lycopersici (57.5\%) implicating an antibiotic like antagonism effect due to the presence of active microorganisms in suspension.

Choanephora cucurbitarum mycelial growth was reduced by 100 per cent in plates amended with compost tea due to the presence of beneficial microorganisms in compost tea utilized the nutrients required for the germination of conidia and prevented the germination or growth of the conidium germ tube leading to lysis of the conidia of the pathogen (Siddiqui et al., 2009). 
To study the field efficacy of compost tea and seaweed formulation on leaf blight of sunflower

Field experiment was conducted to evaluate the relative efficacy of compost tea and seaweed formulation against Alternaria blight of sunflower during 2018-19 at Zonal Agricultural Research Station (ZARS), Gandhi Krishi Vignana Kendra, Bengaluru.

\section{Growth parameters}

The plant height of sunflower recorded at 90 DAS (Table 2) was found significantly higher in all the treatments compared to control $(184.84 \mathrm{~cm})$. Foliar spray of compost tea (1:10) @ 30,45 DAS and propiconazole @ 1 $\mathrm{mlL}^{-1}$ at 60 DAS (T3) recorded maximum plant height $(245.93 \mathrm{~cm})$ which was on par with other treatments. These results are in accordance with El-Din and Hendawy (2010) who reported that plants sprayed with compost tea significantly improved plant growth characters expressed as plant height, fresh and dry weight of aerial parts, number of suckers and seed weight of Borago officinalis compared to untreated plants.

The effect of different treatments on the number of leaves per plant was recorded at 90 DAS was significantly higher in all the treatments compared to control (5.96). Maximum number of leaves was recorded in foliar spray of compost tea (1:10) @ 30,45 DAS and propiconazole @ $1 \mathrm{mlL}^{-1}$ at $60 \mathrm{DAS}$ (9.35) which is on par with foliar spray of seaweed formulation (LBD-1) @ $2 \mathrm{mlL}^{-1}$ at 30,45 DAS and propiconazole@ $1 \mathrm{mlL}^{-1}$ at 60 DAS (8.33) followed by other treatments. Foliar spray of compost tea @ 30,45 DAS and propiconazole @ 60 DAS (T3) was significantly superior over other treatments and remaining other treatments were on par with each other.
Similar type of results were obtained by Siddiqui et al., (2008) who reported that compost extracts promoted significant enhancement on morphological characters of okra such as shoot length, tap root length, number of leaves per plant, and leaf area variations in respect to other treatments.

The stem girth of sunflower recorded at 90 DAS was found significantly higher in all the treatments compared to untreated control $(2.73 \mathrm{~cm})$. Among the treatments, maximum stem girth was recorded in foliar spray of compost tea (1:10) @30,45 DAS and propiconazole@1 mlL $\mathrm{ml}^{-1}$ at $60 \mathrm{DAS}$ (4.60 $\mathrm{cm})$ which is on par with foliar spray of seaweed formulation (LBD-1) @ $2 \mathrm{mlL}^{-1}$ at 30, 45 DAS and propiconazole @ $1 \mathrm{mlL}^{-1}$ at 60 DAS $(4.20 \mathrm{~cm})$ and foliar spray of propiconazole@1 $1 \mathrm{mlL}^{-1}$ at 45 and 60 DAS $(4.16 \mathrm{~cm})$.

Due to fermentation more accumulation of nitrates in the compost tea may take place which will contribute to increase in biomass of the compost tea treated plants. Similar results were reported in lettuce growth by Kim et al., (2015).

\section{Chlorophyll content}

The SPAD value of sunflower recorded at 90 DAS (Table 3) was significantly higher in all treatments compared to the untreated control (30.18). Among the treatments, highest SPAD value was recorded in foliar spray of compost tea (1:10) @ 30,45 DAS and propiconazole @ $1 \mathrm{mlL}^{-1}$ at 60 DAS (42.97) and it was followed by foliar spray of seaweed formulation (LBD-1) @ $2 \mathrm{mlL}^{-1}$ at 30,45 DAS and propiconazole @ $1 \mathrm{mlL}^{-1}$ at 60 DAS (41.22), foliar spray of propiconazole @ $1 \mathrm{mlL}^{-1}$ at 45 and 60 DAS (39.65) and foliar spray of mancozeb @ $3.0 \mathrm{gL}^{-1}$ at 45 and 60 DAS (37.07). However, chlorophyll content in foliar spray of compost tea @ 30,45 DAS 
and propiconazole @ 60 DAS (T3) was superior over all other treatments.

These results are in accordance with Naidu et al., (2013) who reported that microbial enriched compost tea increased significantly chlorophyll content in muskmelon plants. Xu et al., (2012) reported that higher chlorophyll content in compost tea treatments could be due to external supply of nitrogen as a foliar spray from the compost tea. Aerated compost tea showed more greenness or more chlorophyll content; this may be due to aeration of compost tea, which may increase the availability of nitrogen and accumulation of nitrogen in plants.

\section{Disease severity}

The effect of different treatments on per cent disease severity was recorded at 50\% flowering stage and is presented in Table 4, Fig. 2. There was significant difference in the treatments with respect to disease severity.
The result obtained revealed that all the treatments reduced the disease significantly compared to the untreated control. Foliar spray of compost tea (1:10) @ 30,45 DAS and propiconazole @ $1 \mathrm{mlL}^{-1}$ at 60 DAS recorded least severity of 10.37 per cent which is on par with T4 (foliar spray of seaweed formulation (LBD-1)@2 $\mathrm{mlL}^{-1}$ at 30,45 DAS and propiconazole @ $1 \mathrm{mlL}^{-1}$ at 60 DAS) 12.32 per cent. The highest disease severity in control plants (T7) was 44.36 per cent.

The results are in accordance with Weltzien and Ketterer (1986) who reported that application of compost tea significantly suppress several diseases including gray mold, apple scab, collar rot, downy mildew, powdery mildew and damping-off. MoralesCorts et al., (2018) showed suppressive effect of aerated compost tea on Rhizoctonia solani and Fusarium oxysporum f. sp. lycopersici on tomato plants.

Table.1 In vitro evaluation of compost tea against A. helianthi

\begin{tabular}{|c|c|c|}
\hline $\begin{array}{c}\text { Concentrations } \\
(\mathbf{\%})\end{array}$ & $\begin{array}{c}\text { Radial growth of pathogen } \\
(\mathbf{m m})\end{array}$ & $\begin{array}{c}\text { Per cent inhibition over } \\
\text { control (\%) }\end{array}$ \\
\hline $\mathbf{2 . 5}$ & 35.00 & 50.00 \\
& & $(44.99)^{*}$ \\
\hline $\mathbf{5 . 0}$ & 34.33 & 51.40 \\
& & $(45.80)$ \\
\hline $\mathbf{1 0 . 0}$ & 33.33 & 52.40 \\
& & $(46.37)$ \\
\hline $\mathbf{1 5 . 0}$ & 32.33 & 53.80 \\
& & $(47.17)$ \\
\hline $\mathbf{2 0 . 0}$ & 29.00 & 58.50 \\
& & $(49.91)$ \\
\hline $\mathbf{2 5 . 0}$ & 27.66 & 60.50 \\
& & $(51.06)$ \\
\hline Control & 70.00 & 0.00 \\
& & $(0.00)$ \\
\hline S. Em \pm & 0.42 & 1.23 \\
\hline C.D @ $\mathbf{1 \%}$ & 2.22 & 6.46 \\
\hline
\end{tabular}

* Figures in parenthesis are arc sine transformed values 
Table.2 Effect of different treatments on growth parameters

\begin{tabular}{|c|c|c|c|}
\hline Treatment & $\begin{array}{l}\text { Plant } \\
\text { height } \\
\text { (cm)\# }\end{array}$ & $\begin{array}{c}\text { Number } \\
\text { of leaves } \\
\#\end{array}$ & $\begin{array}{c}\text { Stem } \\
\text { girth }(\mathbf{c m}) \\
\#\end{array}$ \\
\hline $\begin{array}{l}\text { T1: Foliar spray of compost tea }(1: 10) @ 30,45 \text { and } \\
\text { 60 DAS }\end{array}$ & $226.74^{\mathrm{a}}$ & $7.35^{\mathrm{b}}$ & $3.74^{\mathrm{bc}}$ \\
\hline $\begin{array}{l}\text { T2: Foliar spray of seaweed formulation (LBD-1) } \\
\text { @ } 2 \mathrm{~mL}^{-1} \text { at } 30,45 \text { and } 60 \mathrm{DAS}\end{array}$ & $224.60^{\mathrm{a}}$ & $7.20^{\mathrm{b}}$ & $3.46^{\mathrm{c}}$ \\
\hline $\begin{array}{l}\text { T3: Foliar spray of compost tea }(1: 10) @ 30,45 \\
\text { DAS and propiconazole @ } 1 \mathrm{~mL}^{-1} \text { at } 60 \mathrm{DAS}\end{array}$ & $245.93^{\mathrm{a}}$ & $9.35^{\mathrm{a}}$ & $4.60^{\mathrm{a}}$ \\
\hline $\begin{array}{l}\text { T4: Foliar spray of seaweed formulation (LBD-1) } \\
\text { @ } 2 \mathrm{mlL}^{-1} \text { at 30,45 DAS and propiconazole @ } \\
1 \mathrm{mlL}^{-1} \text { at } 60 \mathrm{DAS}\end{array}$ & $236.27^{\mathrm{a}}$ & $8.33^{\mathrm{ab}}$ & $4.20^{\mathrm{ab}}$ \\
\hline $\begin{array}{l}\text { T5: Foliar spray of propiconazole @ } 1 \mathrm{mlL}^{-1} \text { at } 45 \\
\text { and } 60 \text { DAS }\end{array}$ & $232.13^{\mathrm{a}}$ & $8.07^{\mathrm{b}}$ & $4.16^{\mathrm{abc}}$ \\
\hline $\begin{array}{l}\text { T6: Foliar spray of mancozeb @ } 3.0 \mathrm{gL}^{-1} \text { at } 45 \text { and } \\
\text { 60 DAS }\end{array}$ & $227.73^{\mathrm{a}}$ & $7.87^{\mathrm{b}}$ & $3.82^{\mathrm{bc}}$ \\
\hline T7: Control & $184.84^{\mathrm{b}}$ & $5.96^{\mathrm{c}}$ & $2.73^{\mathrm{d}}$ \\
\hline S.Em \pm & 11.09 & 0.39 & 0.23 \\
\hline CD at $5 \%$ & 34.18 & 1.21 & 0.71 \\
\hline
\end{tabular}

\# Mean of three replications

Table.3 Effect of different treatments on chlorophyll content

\begin{tabular}{|c|c|}
\hline Treatment & $\begin{array}{l}\text { Chlorophyll } \\
\text { SPAD value \# }\end{array}$ \\
\hline $\begin{array}{l}\text { T1: Foliar spray of compost tea }(1: 10) @ 30,45 \text { and } 60 \\
\text { DAS }\end{array}$ & $33.34^{\mathrm{f}}$ \\
\hline $\begin{array}{l}\text { T2: Foliar spray of seaweed formulation (LBD-1) @ } 2 \\
\text { mlL }{ }^{-1} \text { at 30, } 45 \text { and } 60 \text { DAS }\end{array}$ & $35.25^{\mathrm{e}}$ \\
\hline $\begin{array}{l}\text { T3: Foliar spray of compost tea }(1: 10) @ 30,45 \mathrm{DAS} \text { and } \\
\text { propiconazole @ } 1 \mathrm{mlL}^{-1} \text { at } 60 \mathrm{DAS}\end{array}$ & $42.97^{\mathrm{a}}$ \\
\hline $\begin{array}{l}\text { T4: Foliar spray of seaweed formulation (LBD-1) @ } 2 \\
\text { mlL }^{-1} \text { at 30, } 45 \text { DAS and propiconazole @ } 1 \mathrm{mlL}^{-1} \text { at } \\
\text { 60 DAS }\end{array}$ & $41.22^{\mathrm{b}}$ \\
\hline $\begin{array}{l}\text { T5: Foliar spray of propiconazole @ } 1 \mathrm{mlL}^{-1} \text { at } 45 \text { and } 60 \\
\text { DAS }\end{array}$ & $39.65^{c}$ \\
\hline T6: Foliar spray of mancozeb @ $3.0 \mathrm{gL}^{-1}$ at 45 and $60 \mathrm{DAS}$ & $37.07^{\mathrm{d}}$ \\
\hline T7: Control & $30.18^{\mathrm{g}}$ \\
\hline S.Em \pm & 0.30 \\
\hline CD at $5 \%$ & 0.94 \\
\hline
\end{tabular}

\# Mean of three replications 
Table.4 Effect of different treatments on disease severity and yield

\begin{tabular}{|c|c|c|}
\hline Treatment & $\begin{array}{c}\text { Disease severity } \\
(\%)\end{array}$ & $\begin{array}{c}\text { Yield } \\
\left(\mathrm{Kg} \mathrm{ha}^{-1}\right) \#\end{array}$ \\
\hline $\begin{array}{l}\text { T1: Foliar spray of compost tea }(1: 10) @ 30,45 \text { and } \\
\text { 60 DAS }\end{array}$ & $\begin{array}{l}21.06^{\mathrm{bc}} \\
(26.73) *\end{array}$ & $1632.80^{b}$ \\
\hline $\begin{array}{l}\text { T2: Foliar spray of seaweed formulation } \\
\text { (LBD-1)@ } 2 \mathrm{mlL}^{-1} \text { at } 30,45 \text { and } 60 \text { DAS }\end{array}$ & $\begin{array}{l}22.76^{\mathrm{b}} \\
(28.82)\end{array}$ & $1692.24^{\mathrm{b}}$ \\
\hline $\begin{array}{l}\text { T3: Foliar spray of compost tea }(1: 10) @ 30,45 \\
\text { DAS and propiconazole @ } 1 \mathrm{mlL}^{-1} \text { at } 60 \mathrm{DAS}\end{array}$ & $\begin{array}{l}10.37^{\mathrm{e}} \\
(18.29)\end{array}$ & $2201.41^{\mathrm{a}}$ \\
\hline $\begin{array}{l}\text { T4: Foliar spray of seaweed formulation (LBD- 1) @ } 2 \mathrm{mlL}^{-1} \\
\text { at 30, } 45 \text { DAS and propiconazole @ } 1 \mathrm{mlL}^{-1} \text { at } 60 \text { DAS }\end{array}$ & $\begin{array}{l}12.32^{\mathrm{e}} \\
(19.42)\end{array}$ & $1928.04^{\mathrm{ab}}$ \\
\hline $\begin{array}{l}\text { T5: Foliar spray of propiconazole @ } 1 \mathrm{mlL}^{-1} \text { at } 45 \text { and } 60 \\
\text { DAS }\end{array}$ & $\begin{array}{l}13.79^{\mathrm{de}} \\
(21.87)\end{array}$ & $1783.77^{\mathrm{b}}$ \\
\hline T6: Foliar spray of mancozeb @ $3.0 \mathrm{gL}^{-1}$ at 45 and $60 \mathrm{DAS}$ & $\begin{array}{l}18.11^{\text {cd }} \\
(25.19)\end{array}$ & $1715.23^{\mathrm{b}}$ \\
\hline T7: Control & $\begin{array}{l}44.36^{\mathrm{a}} \\
(42.73)\end{array}$ & $1262.81^{\mathrm{c}}$ \\
\hline S.Em \pm & 1.48 & 118.10 \\
\hline CD at $5 \%$ & 4.56 & 363.93 \\
\hline
\end{tabular}

* Figures in parenthesis are arc sine transformed values \# Mean of three replications

Plate.1 In vitro evaluation of compost tea at different concentrations on radial growth of $A$. helianthi

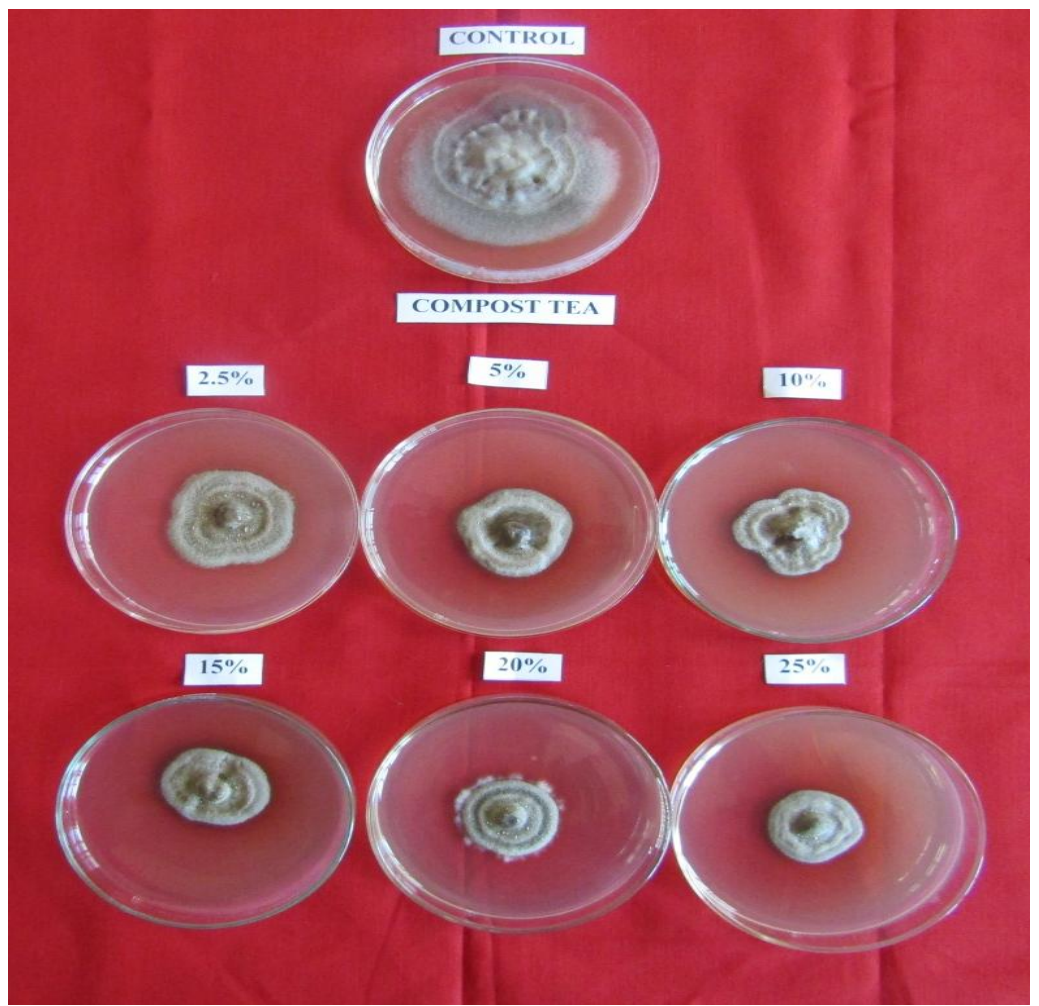


Int.J.Curr.Microbiol.App.Sci (2021) 10(01): 1245-1267

Fig.1 Effect of compost tea on radial growth of A. helianthi

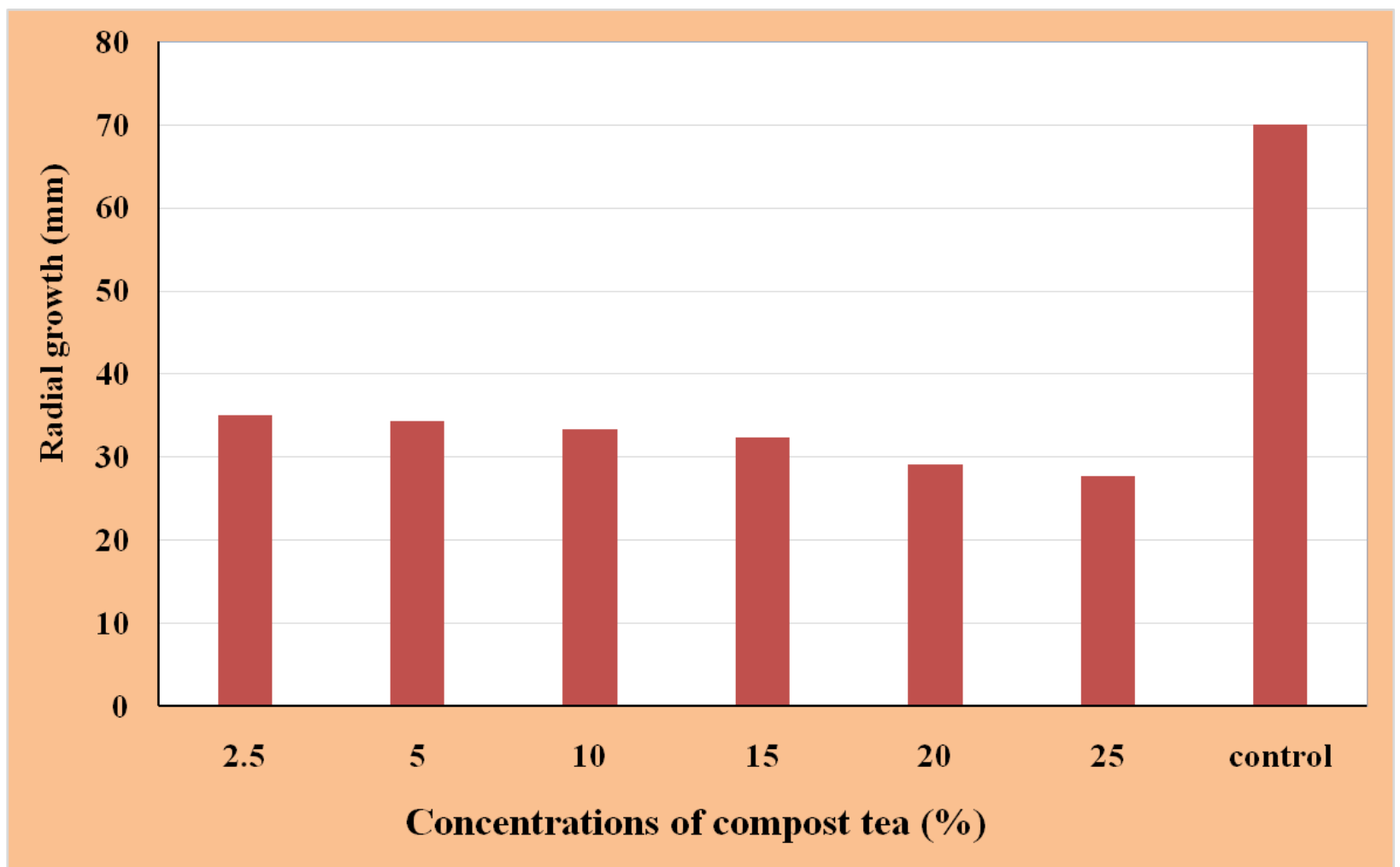


Int.J.Curr.Microbiol.App.Sci (2021) 10(01): 1245-1267

Fig.2 Effect of different treatments on disease severity of Alternaria blight of sunflower

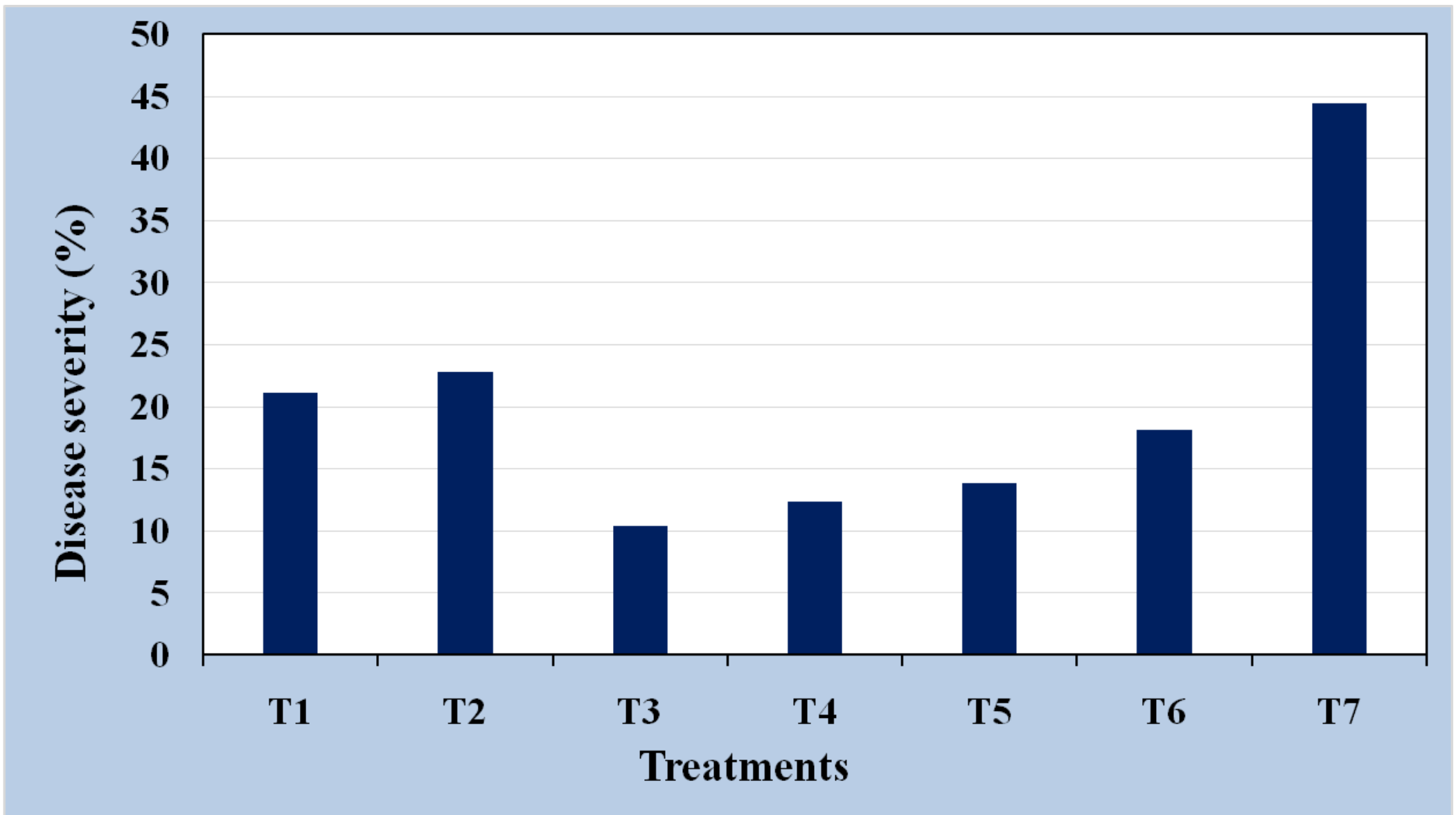


Int.J.Curr.Microbiol.App.Sci (2021) 10(01): 1245-1267

Fig.3 Effect of different treatments on yield of Alternaria blight of sunflower

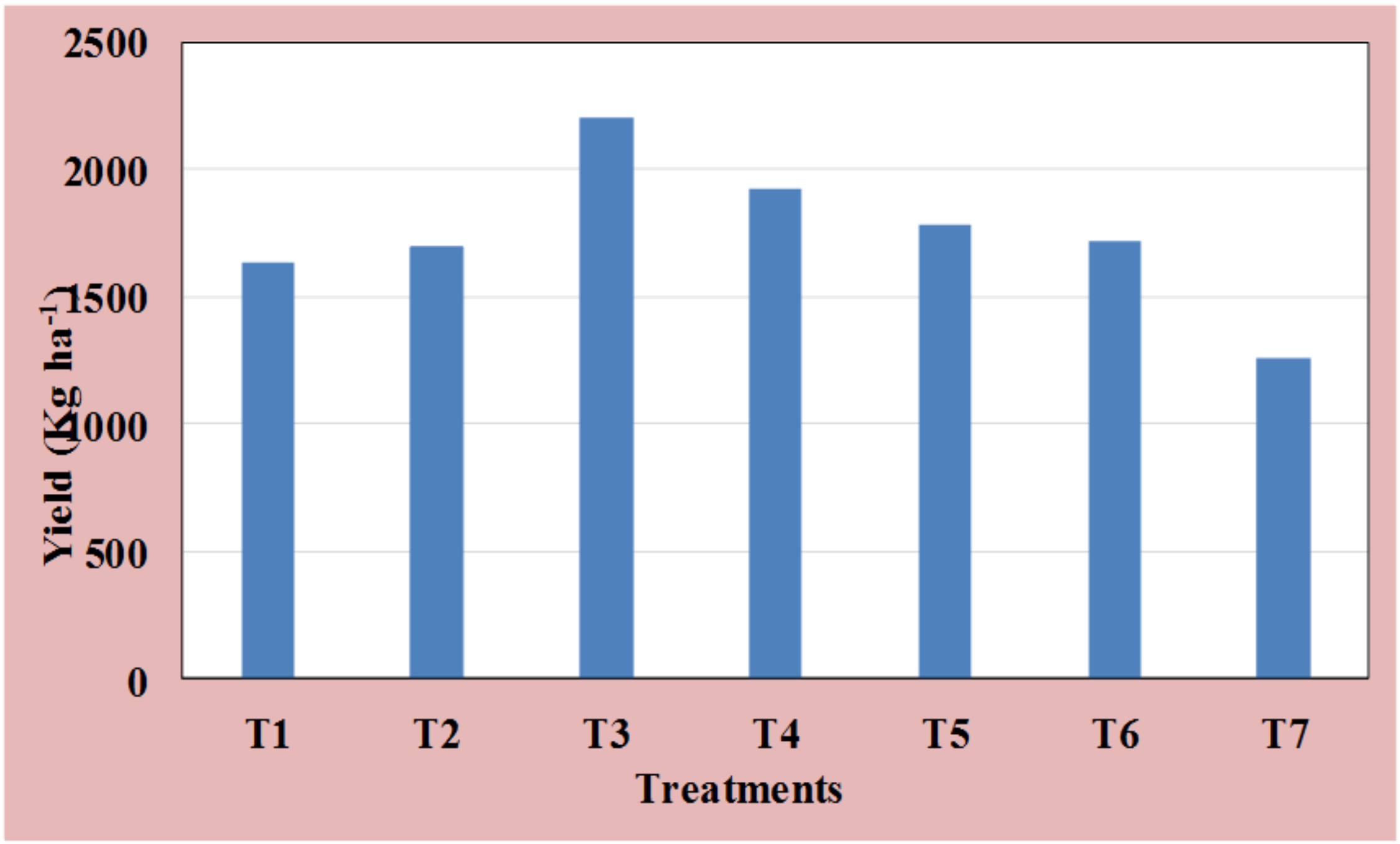




\section{Seed yield}

The seed yield obtained in the different treatments is presented in Table 4, Fig. 3. All the treatments were significantly superior over control. Foliar spray of compost tea (1:10) @ 30,45 DAS and propiconazole @ 1 $\mathrm{mlL}^{-1}$ at 60 DAS recorded significantly higher seed yield of $2201 \mathrm{Kg} \mathrm{ha}^{-1}$ followed by $\mathrm{T} 4$ (Foliar spray of seaweed formulation (LBD-1) @ $2 \mathrm{mlL}^{-1}$ at 30,45 DAS and propiconazole @ $1 \mathrm{mlL}^{-1}$ at $\left.60 \mathrm{DAS}\right) 1928 \mathrm{Kg} \mathrm{ha}{ }^{-1}$. Whereas,lowest seed yield (1262 Kg ha ${ }^{-1}$ ) was obtained in treatment T7 (control).

Similar type of results were obtained by Lopez-Martin et al., (2018) who reported that garden waste compost tea increased the yield by 9.47 per cent on potato against Rhizoctonia solani. Hassan et al., (2013) reported that foliar spray of both compost tea and Bavistin was found 79.62 per cent higher yield over control.

\section{References}

Allen, S. J., Brown, J. F. and Kochman, J. K., 1983, Effect of temperature, dew period and light on the growth and development of Alternaria helianthi. Phytopathol., 73 : 893-896.

Anil, V. S., Roopashree, K. M. and Suvarna, V. C., 2017, Bio-dynamic compost tea suppresses the phytopathogens of late blight and rice blast diseases. J. Soil Biol. Ecol, 37: 55-69.

Anonymous, 2017, Ministry of Agriculture, Govt. of India. www.indiastat.com

Balasubramanyam, N. and Kolte, S. J., 1980, Effect of Alternaria blight on yield components, oil content and seed quality of sunflower. Indian. J. Agric. Sci., 50:701-706.

El-Din, A. A. E. and Hendawy, S. F., 2010, Effect of dry yeast and compost tea on growth and oil content of Borago officinalis plant. Res. J. Agric. Biol. Sci., 6(4): 424-430.

Haggag, W. M. and Saber, M. S. M., 2007, Suppression of early blight on tomato and purple blight on onion by foliar sprays of aerated and non-aerated compost teas. J. Food Agric. Environ., 5(2): 302-309.

Hassan, M. R., Hossain, I., Islam, M. R. and Khokon, M. A. R., 2013, Comparative efficacy of compost, compost tea, poultry litter and bavistin in controlling diseases of chili. Prog. Agric., 24(1-2): 39-44.

Kim, M. J., Shim, C. K., Kim, Y. K., Hong, S. J., Park, J. H., Han, E. J., Kim, J. H. and Kim., S. C., 2015, Effect of aerated compost tea on the growth promotion of lettuce, soybean, and sweet corn in organic cultivation. J. Plant Pathol.3: 259-268.

Lopez-Martin, J. J., Morales-Corts, M. R., Perez-Sanchez, R. and Gomez-Sanchez, M. A., 2018, Efficiency of garden waste compost teas on potato growth and its suppressiveness against Rhizoctonia. Poljoprivreda i Sumarstvo, 64(4): 7.

Luo, M., Purdy, H. and Avis, T. J., 2019, Compost bacteria provide antifungal activity against grey mold and Alternaria rot on bell pepper fruit. Bot., 97(3): 221230.

Morales-Corts, M. R., Perez-Sanchez, R. and Gomez-Sanchez, M. A., 2018, Efficiency of garden waste compost teas on tomato growth and its suppressiveness against soilborne pathogens. Scientia Agricola, 75(5): 400-409.

Naidu, Y., Meon, S. and Siddiqui, Y., 2013, Foliar application of microbial enriched compost tea enhances growth, yield and quality of muskmelon (Cucumis melo L.) cultivated under fertigation system. Scientia horticulturae, 159: 33-40.

Panse, V. G. and Sukhatme, P. V., 1967, 
Statistical methods for agricultural workers. ICAR, Agri. Res., New Delhi.

Reddy, P. C. and Gupta, B. M., 1977, Disease loss appraisal due to leaf blight of sunflower incited by Alternaria helianthi. Indian Phytopath., 30: 569570.

Shankergoud, I., Shadakshari, Y. G., Parameshwarappa, K. G., Chandranath, H. T., Katti, P. and Mesta, R. K., 2006, Sunflower and castor research in Karnataka-An overview. Univ. Agric. Sci., Dharwad (India), 1-41.

Sharma, H. S., Fleming, C., Selby, C., RAO, J. R. and Martin, T., 2014, Plant biostimulants: a review on the processing of macroalgae and use of extracts for crop management to reduce abiotic and biotic stresses. J. Appl. Phycol., 26: 465-490.

Siddiqui, Y., Meon, S., Ismail, M. R. and Ali, A., 2008, Trichoderma-fortified compost extracts for the control of Choanephora wet rot in okra production. Crop Prot., 27(3-5): 385390.

Siddiqui, Y., Meon, S., Ismail, R. and Rahmani, M., 2009, Bio-potential of compost tea from agro-waste to suppress Choanephora cucurbitarum L. the causal pathogen of wet rot of okra. Biol. Control, 49(1): 38-44.

Vincent, J. M., 1947, Distortion of fungal hyphae in the presence of certain inhibitors. Nature, 159: 239-241.

Weltzien, H. C. and Ketterer, N., 1986, Control of downy mildew, Plasmopara viticola (de Bary) Berlese et de Toni, on grapevine leaves through water extracts from composted organic wastes. $J$. Phytopathol., 116(2): 186-188.

Xu, D. B., Wang, Q. J., Wu, Y. C., Yu, G. H., Shen, Q. R. and Huang, Q. W., 2012, Humic-like substances from different compost extracts could significantly pro-mote cucumber growth. Pedosphere, 22: 815-24.

\section{How to cite this article:}

Shadab M. Khatib, K. Karuna and Dattatreya. 2021. In vitro and Field Evaluation of Compost tea and Seaweed Formulation on Leaf Blight of Sunflower. Int.J.Curr.Microbiol.App.Sci. 10(01): 1245-1267. doi: https://doi.org/10.20546/ijcmas.2021.1001.149 